\title{
Lewis Namier: Nationality, Territory and Zionism
}

\author{
D. W. Hayton ${ }^{1}$
}

Published online: 30 January 2017

C The Author(s) 2017. This article is published with open access at Springerlink.com

\begin{abstract}
The historian Sir Lewis Namier, born Ludwik Bernstein in Russian Poland in 1888 and brought up in east Galicia, was an unusual figure amongst Jewish theorists of nationalism. His father's family were assimilated Jews, and Namier grew up in a household that was thoroughly Polonised. Though registered as Jewish, he was not circumcised and was brought up in ignorance of Jewish traditions; his parents and sister subsequently converted to Catholicism. Unlike other Jewish intellectuals, he had no love for the Austro-Hungarian monarchy nor for German culture in general, and as a young man was an ardent pan-Slavist. Education at Oxford also imprinted in him a lifelong admiration for the British Empire, which he regarded as a force for good because it embodied the libertarian ethos inherent in Britain's national traditions. In his early writings, he defined nationality principally by race, and took religion, and attachment to a particular territory, as the principal markers of racial identity. This analysis derived chiefly from his observation of the history and geopolitics of central and eastern Europe, but he was also able to apply the same calculus to the "Anglo-Saxon" empires of the Atlantic world. These ideas, which he refined in later life but never abandoned, also fuelled a growing attachment to Zionism, accelerated by his own experiences of anti-Semitism, and his observation of the maltreatment of Jews in eastern Europe, of which he became increasingly aware through his role as an expert adviser in the British Foreign Office in 1916-1920.
\end{abstract}

Keywords Sir Lewis Namier $\cdot$ Nationality $\cdot$ Nationalism $\cdot$ Race $\cdot$ Empire $\cdot$ Zionism

\section{Introduction}

In 1930, when the British historian Lewis Namier (1888-1960) was included for the first time in Who's Who, he described himself as 'a Russian subject by birth, naturalised British, a Jew by race' (Namier 1930, p. 2268). Born Ludwik Bernstein in Russian Poland, Namier spent most of his childhood and adolescence in east Galicia, at that time under Habsburg rule, before coming to

D. W. Hayton

D.Hayton@qub.ac.uk

1 School of History, Anthropology, Politics and Philosophy, Queen's University Belfast, Belfast, Northern Ireland BT7 1NN, UK 
Britain as a student, first at the London School of Economics and then at Balliol College, Oxford. He was naturalised in 1913, having Anglicised his name as Lewis Bernstein Namier, basing this invented surname on what his family regarded as their ancestral name of Niemirowski. In the winter of 1913-1914, he worked in New York and briefly considered training as a lawyer, with a view to making a professional career in the USA, but on the outbreak of the First World War he enlisted to serve his adopted king and country, and, although a very active Zionist in the 1920s and 1930s never seriously considered leaving England again.

Namier is an unusual figure among Jewish theorists of nationalism, who themselves of course comprise a very variegated group. In the first place, he would himself have been uncomfortable with the notion that he was a 'theorist'. Many commentators have characterised him as an arch-enemy of theory. His early writings discuss political ideas and sentiments only in connexion with specific political action, whilst in later life an increasingly conservative outlook inclined him to dismiss ideology and ideologues, especially those on the left. During one private rant, he described Karl Marx as 'a typical Jewish half-charlatan, who got hold of quite a good idea and then ran it to death just to spite the Gentiles' (Berlin 1980, p. 65). In most of his publications on nineteenth- and twentieth-century European history, Namier's views on nationality and nationalism were implicit rather than explicit. This was particularly true of the period during and immediately after the First World War, when he contributed to magazines and newspapers (especially the New Europe, the New Statesman, and the Manchester Guardian) and compiled minutes, reports and memoranda on Austro-Hungarian and Polish affairs whilst working for the Foreign Office. Some later pieces were more discursive, his Raleigh Lecture to the British Academy in 1944, published as 1848: the revolution of the intellectuals (Namier 1944); a conference paper 4 years later in Rome, summarising his views on 'Nationality and history' (Namier 1958a); and his Creighton lecture at London University in 1952 on 'Basic factors in nineteenth-century European history' (Namier 1958b). But this was a meagre proportion of a remarkably large corpus of historical work. The remainder of his writing about nationalism was instrumental; that is to say, it occurred in the context of advancing arguments for or against political action. It might indeed be argued that his thinking about nationalism was always instrumental, a means of explaining historical developments whose basis lay in political conflict.

\section{Background and Early Life}

Namier's family background also had peculiar elements. In saying this, one has to remember that his personal history still has puzzles and obscurities, largely because much of the evidence that has been used by commentators on his life comes from Namier himself, recorded in the biography published 10 years after his death by his widow, Julia, which was heavily based on Namier's own recollections, dictated to her in his old age (Namier 1971). He had decided in 1955 that she was to write his biography, in order to forestall a 'tribe' of hacks who, he thought, would rush to devour his reputation after his death (Namier 1971, pp. 305-306). And there were rich pickings for vultures in search of scandal - the failure of his first marriage, his various love affairs and his alienation from his immediate family. The fact that Namier had continually revisited his past on the psycho-analyst's couch from the early 1920s must raise concerns about the possibility that he had polished some 'false memories'. There is also the problem of Julia herself, who allowed her own prejudices to influence the portrait she crafted. 
A Russian Orthodox exile, she was intensely spiritual, whereas Namier, until his very last years, was loudly anti-clerical and suspicious of all religion. So, when she presented his life as a constant striving towards God, many of his close friends, like Isaiah Berlin, simply did not believe it (Berlin 2013; see also Paton 1962; Sutherland 1971).

Namier's reminiscences - as processed by Julia — must therefore be balanced against other contemporary evidence. Although his grandparents on both sides were observant Jews, his father Józef and mother Anna abandoned any pretence at religious practice before he was born. Namier was registered as Jewish, possibly to please his domineering paternal grandmother, but was not circumcised nor was he brought up as a Jew. His parents called themselves Roman Catholics, as did several aunts and uncles, and eventually his father, mother and sister were all baptised. His sister married a Roman Catholic Polish gentleman, and her children were raised as Catholics. Namier's mother, sister and nieces survived the Second World War by moving from Lwów, where their racial origin was known, to Warsaw, where they lived in relative safety as Polish Catholics outside the ghetto. ${ }^{1}$ Whilst growing up, however, Namier could not have been ignorant of his race, since he spent a good deal of time with his maternal grandfather, Teodor Sommerstein, a Galician landowner and businessman whose family retained a strong sense of their Jewishness; indeed, one relation on his mother's side was a prominent Zionist leader, Emil Sommerstein (Jewish Chronicle 1960; Namier 1954).

Beyond the family circle, the young Namier had little contact with other Jews. He had been born in Russian Poland, in a summerhouse owned by his paternal grandfather, but his parents soon moved south to the Habsburg lands. Józef, having failed to prosper in his chosen profession of advocate, went to work for his wealthy father in law, managing property and factories in east Galicia. Namier's childhood was mainly spent in the countryside, on his grandfather's estates, punctuated by visits to Tarnopol, Lemberg (as Lwów was then known), and occasionally to Vienna. Eventually, Józef acquired an estate of his own, at Koszylowce, 2 hours away by horse and trap from the nearest railway station, on an area of high ground above the long valley of the Dzurin river, a tributary of the Dniester. For the most part, education was conducted at home. The Bernsteins were assimilationists par excellence, conducting themselves in the manner of the Polish gentry who constituted the Galician landowning class. They spoke French and Polish at home and had nothing in common with the stetl Jews nor with the vast majority of the Jewish population in neighbouring towns. Namier did not attend synagogue - as an adult, his ignorance of Jewish traditions would make him alarmed at the prospect (Rose 1980) - and Józef and his family considered Yiddish an inexpressibly vulgar language, though some Viennese cousins were brought up to speak it (Schutz 1994). His Jewish heritage thus meant little to him, except that the family cherished the fact of his grandmother's direct descent from the most important and revered Jewish intellectual of the modern era, Elijah ben Solomon (1720-1797), the 'Gaon' (genius) of Vilna (Vilnius) (Stern 2013). The adult Namier was said by friends to flourish at every opportunity his descent from the Gaon (Toynbee 1967), and occasionally, he inserted such references into his writings (see for example Namier 1942). But this only underlined his alienation from Galician Jewry, since the numerous Hasidic Jews in the province were imbued with hostility to the memory of the Gaon, a strenuous opponent of their doctrines and practices. $^{2}$

\footnotetext{
${ }^{1}$ Private information.

2 One of Isaac Babel's stories of the Polish-Soviet war of 1919-1921 depicts a bitter debate between Galician Jews, in which the Gaon was roundly denounced by the Hasidim (Babel 1961, p. 126).
} 
At the same time, Namier was aware that he and his family were not accepted by the Galician gentry, and he was wont to recall an incident when he had overheard local squires making fun of his father as a Jew seeking to be more Polish than the Poles (Namier 1971). As a young man, he treasured the prospect of succeeding as master of Koszylowce, and of living the life of a Galician gentleman, but this was a pipe dream. Although in some essays in the 1920s he allowed himself to lament the demise of the aristocratic order in eastern Europe as the inundation of strongholds of cultural sophistication under a tide of brutish ignorance (Namier 1920; September 23, 1931), ${ }^{3}$ his political sympathies were with the peasantry rather than their masters. Here again, there was some ambivalence, deriving from the fact that peasant society was another world from which he had been excluded. He was not permitted to mix with local children and was kept away from village schools. However, he accompanied a housemaid to church and was impressed by the atmosphere of Uniate services. He and his sister also had daily contact with the estate servants, from whom they were able to pick up knowledge of Ukrainian despite their father forbidding them to speak the language (which he regarded as a dialect). Probably these prohibitions were counter-productive, leading Namier to idealise some aspects of the peasants' culture - particularly their religious devotion — which he could only observe from outside.

\section{Pan-Slavist and British Imperialist}

From this wholly deracinated environment, neither Jew, nor Pole, nor Ukrainian, but, as he his father once told him, 'a nothing' (Namier 1971, pp. 34-35), the young Namier developed a political sensibility which was highly unusual for an east European Jew. He became a panSlavist (Ng 2004). Abandoning the reverence for German ideas and culture which was characteristic of east European Jewry, and which had induced grandfather Sommerstein to send Namier's mother to be educated at Dresden, he turned instead to Russia for inspiration. Dostoyevsky became his favourite novelist, since, as Namier saw it, Dostoyevsky's writing offered a window into the Russian spirit. Namier's aunt, Anka, recalled visits to her family in Vienna in the early 1920s at which Ludwik talked a great deal about Dostoyevsky, 'and if he saw we did not have on our shelves some good book, by or about him, would bring it round the next day' (Namier 1971). The corollary to Russomania was Germanophobia. With the exception of Goethe, whom he could quote at will, Namier had little time for any aspect of German culture. His first book, a short account of the origins of the First World War, entitled Germany and Eastern Europe, located the prime cause of the European conflict in Germany's militarism and craving for eastward expansion; it was, he wrote, merely the latest episode in the age-old historical struggle of Teuton and Slav (Namier 1915).

The most important source of Namier's pan-Slavism was one of his private tutors. Edmond Weissberg was a brilliant freelance journalist with a dynamic personality and advanced views, who organised a socialist group in Lemberg. His later career was the stuff of legend; after 1939, he carried out hair-raising acts of bravery in the Polish underground before being murdered by the Nazis. As a young man, his irruption into the Bernstein household made an extraordinary impact. He was not only a vibrant character, with principles which he was brave enough to put into practice, but was also handsome and athletic. He captivated Namier's mother and sister and seems to have aroused in his adolescent pupil a kind of hero-worship

\footnotetext{
${ }^{3}$ See also his review of I. L. Evans, The agrarian revolution in Rumania in Nation and Athenaeum, 12 July 1924, which questioned the level of sophistication attained by the aristocracy in Rumania (Namier 1924b July 12).
} 
(Namier 1971). Namier followed Weissberg's example and became an active socialist, almost certainly on the nationalist side of the Polish Socialist Party, the faction headed by Józef Piłsudski, which in 1906 split from the hard-line Marxists (Davies 2005; Ng 2005). It was probably these political principles, rather than, as Namier himself remembered, the antiSemitism of Polish nationalist students, that made him feel isolated and unhappy when he went to university in Lemberg in 1906 (Namier 1971). The Polish Socialist Party was then at war with itself, whilst the Zionist groups amongst the student body would have had little time for an assimilationist Jew (Shanes 2012). So, Namier was removed, first to Lausanne, and then for a term to the L.S.E., where he promptly joined the Fabian Society (Fabian News 1907). Once he arrived in England, and especially when he went up to Oxford, his socialist fervour began slowly to abate, though he still gave the father of an undergraduate friend the impression that he was a nihilist, and throughout his time at the Foreign Office showed an instinctive sympathy with the left in Polish and Czech politics (Wingate 1914). Piłsudski remained a hero of sorts until throwing in his lot with right-wing nationalists in 1919, after which his pedestal was occupied by the Czech Tomáš Masaryk and, more fleetingly, by the Austrian socialist leader Otto Bauer (Namier 1918).

By this time, Namier's pan-Slavist enthusiasm had been reinforced by his understanding of the dynamics of European geopolitics. Here the most profound influence, beyond his own reading and thinking about history, was one of his teachers at the L.S.E., the only one whose lectures he had enjoyed, the geographer Halford Mackinder. These lectures on 'geographical factors in the shaping of history' drew on Mackinder's pioneering studies in geopolitics and in particular his 'heartland theory', which identified Eurasia as the most important part of the global landmass, and focused on eastern Europe as the 'pivot area', the key to control of the 'heartland' and thus of the world's resources (Mackinder 1904, pp. 421-437; Namier 1971, p. 72). Mackinder's theory underpinned the argument presented in Germany and Eastern Europe. Similarly, Namier's lengthy commentaries on Polish politics between 1917 and 1920 were grounded in the belief that the potential for German expansion had to be contained and that Russia must be the principal counterpoise to Germany. This he saw as the root of the Polish problem. He did not oppose the right of the Poles to self-determination but was alarmed at the prospect of building up a powerful Polish state, which would antagonise Russia and play into the hands of the Germans. What had to be avoided at all costs was the bringing together of Russia and Germany to attack Poland (Namier 1918).

In the meantime, Namier's transposition to Britain, and his adoption of British nationality, added a further complication. After several false starts in his university education, he found a home in Balliol. He was able to ignore the entrenched anti-Semitism of Edwardian Oxford, perhaps because little of this was openly expressed, and in any case, his social antennae were poorly developed. Not even his failure to secure an All Souls' fellowship in 1911 and 1912, when 'the warden and majority of fellows shied at his race', could persuade him that he had suffered discrimination (Namier 1971). He always took the outward behaviour of undergraduates and fellows at face value and, indeed, did make many long-lasting friendships. Presenting himself as the son of a landowner, whilst failing to point out that his father had only recently acquired this status (Leeper 1908; Oman 1917), he revelled in the company of the English upper classes, and contrasted Britain's open elite, where for centuries, a business fortune had been no barrier to social advancement, with the feudal aristocracies of eastern Europe that excluded men like his grandfathers (Namier 1966). He also noted the historical rootedness of the English aristocracy, which again contrasted with the 'colonial' character of Galician landlords. And the residual socialist in him was attracted to the specific ethos of 
Balliol; in particular, he came to revere his principal patron in the college, A. L. Smith, a man with deeply held Christian socialist values (Smith 2004). Namier absorbed Smith's conviction of the moral purpose behind Britain's colonial mission, a belief to which he would adhere throughout his life. A college friend described him in 1911 as 'a keen student of Anglo-Saxon institutions and ways and ... enthusiastic for our civilisation, which he regards as the only genuinely liberal one', certainly in comparison with empires in which he had grown up, the oppressive autocracy of Tsarist Russia and the 'hugger-mugger' of Austria-Hungary (Bell 1911; Ng 2004; Namier 1971). His protracted search for a sense of belonging had ended at Balliol, and this new loyalty extended to the British Empire, and its governing class.

\section{Zionist}

But even though he had been able to ignore anti-Semitism at Oxford, Namier was gradually coming to be more conscious of his Jewishness and exercised by the plight of Jews in eastern Europe. Exactly when he became actively interested in Zionism is unclear. As in much else, Julia Namier's biography (and a monograph on her husband's contribution to the Zionist cause for which she was unable to find a publisher (Namier 1959)) depended on Namier's own recollections, in this case preserved in a manuscript memoir which he had drafted before their marriage (Namier 1961). He claimed to have been drawn to Zionism when he went to study at Lausanne, and there are indications that at Oxford he was interested in, and personally affected by, the plight of persecuted Jews (Namier 1959; Rose 1980). But it seems to have been his experiences in the Foreign Office that concentrated his mind. Reading foreign press reports, diplomatic despatches and intelligence intercepts exposed him not only to the details of pogroms in eastern Europe but also to the extent of anti-Semitism amongst elements of the Polish right and, what was perhaps worse, amongst British journalists, members of parliament and even civil servants and diplomats. Personal attacks on him, orchestrated by the Polish National Democrats, produced articles in the press and questions in the House of Commons (Latawski 1987). All this helped to push him towards the conviction that in the last resort Jews could only guarantee their survival through establishing themselves in an independent state. By 1920, he was in contact with Chaim Weizmann and the Zionist Organisation (Namier 1971, 1959, p. 7; Namier 1919). He attended his first Zionist congress in 1925 and in the same year was approached to succeed Leonard Stein as the organisation's political secretary, a position he eventually took up in 1929, for a momentous 2-year term (Rose 1980).

Namier was never comfortable in the Zionist Organisation. Although he venerated Weizmann as a prophetic leader (Namier 1947), he was often exasperated by Weizmann's behaviour, and his opinions of most other Zionist leaders were barely printable. Namier never suffered gladly those whom he regarded as self-important fools, and when so many innocent Jewish lives were at stake, he would not suffer them at all. Nor did he ever wish to submit himself to the Jewish religion, distrusting rabbis as much as he disliked all other clerics, except the Anglican clergy, whom he regarded as socially and politically innocuous. Indeed, before his marriage to Julia in 1947, he agreed to be baptised into the Church of England, a decision that disgusted and infuriated Weizmann and caused a permanent rupture between the two men (Berlin 1961; Namier 1951). But even though he was never elected to the Zionist executive, and was sometimes treated shabbily, he remained a devoted servant of the Zionist cause. Throughout the 1930s and during the Second World War, he lobbied politicians and officials, drafted minutes, wrote letters to the press and worked hard to arrange for the resettlement of academic refugees from Nazi-occupied Europe. 


\section{Definitions of Nationality}

Namier's musings about the nature of nationality arose in four contexts, all of which were directly connected to the First World War and its aftermath, and to his own personal struggles, as a pan-Slavist Galician Jew, a specialist adviser in the British Foreign Office and an increasingly committed Zionist. First, in his thinking about nineteenth-century European history and the causes of conflict, in which he sought to explain the emergence of belligerent, 'imperialist' nationalisms after 1848, especially in Germany. Second, in his analysis of the death throes of the Austro-Hungarian empire, which he saw as a conflict between the dominant nationalities, German, 'Magyar' and Polish, and the subject Slavs, an interpretation rehearsed in private memoranda and in newspaper and magazine articles before being summarised in a lengthy chapter in the official history of the Paris peace conference (Namier 1924a). Third, in his efforts in 1917-1920 to alert British politicians and Foreign Office mandarins to the problems posed by an expansionist Polish republic, which was claiming lands in which ethnic Poles were a minority. And finally, in his anxiety over the plight of Jews in central and eastern Europe, which demanded resolution in the establishment of a Jewish homeland in Palestine. His ideas about nationality and nationalism were thus formed in the crucible of the first great European-wide conflict and the revolutions that ensued when the eastern empires-Russia, Austria-Hungary and Ottoman Turkey - collapsed. They were developed and refined in later years but did not fundamentally alter. The 'low, dishonest decade' of the 1930s drove him to desperation, and heightened his Germanophobia, to the extent that he could describe Hitler as a wholly representative type, who voiced 'the deepest instincts of Germany'. After the Second World War, he would not agree to meet any German unless provided in advance with evidence that the person concerned had actively opposed the Nazi regime (Namier 1959; Rose 1980). However, in comparison with what he had already written about German militarism in 1915, this was only a difference of degree.

Of the three criteria which Namier saw as having historically provided definitions of nationality - a common language, a racial and cultural identity and the attachment of people to a particular territory - linguistic nationalism seemed to him the most problematical. Not that he rejected language as a marker of nationality, far from it. He recognised its crucial importance to the birth of a Slavic consciousness amongst east European peoples in the nineteenth century, especially the Czechs, who were 'the leaders and pioneers of linguistic pan-Slavism' (Namier 1914). He was also happy to acknowledge the essential commonality of German-speaking Austria with the rest of Germany, once the Austrian state had been shorn of its non-German empire, and he was an insistent advocate of Anschluss in the immediate aftermath of the First World War (Namier 1923, p. 572, 1931). And of course, languageHebrew rather than Yiddish - formed for him an important element of Jewish identity, though not the most important. But linguistic nationalism was also bound up with mid-nineteenthcentury liberalism, the creed of his father and grandfather, against which he had rebelled violently in adolescence and to which he never reconciled himself. These middle-class liberals had reawakened national consciousness in the countries of central and eastern Europe but had failed to liberate the oppressed Slav nations, who after 1867, under the politically reconstructed Austro-Hungarian empire, were worse off than before. Moreover, in Germany, the liberals of 1848 had opened the way for an aggressive, militaristic form of nationalism. Namier believed that the German national character was dominated by the will to 'power, preponderance and dominion', and in his Waynflete Lectures in Oxford in 1948 argued that the liberal nationalists of the Frankfurt parliament were infected with the same yearning for imperialist expansion as 
the most bellicose Prussian conservatives (Namier 1922-1923, 1949; Taylor 1983). Calls for state boundaries to reflect linguistic geography were also used by Polish 'imperialists' in 1917-1920, in order to justify expansion in Lithuania, Belarus and Galicia. In those parts of eastern Europe which Namier knew best, and with which he was most closely concerned, the mosaic of national communities caused by centuries of migrations and colonisation projects offered endless opportunities to unscrupulous politicians to demand lands to which their states were not entitled by other criteria.

In his lecture in Rome in 1948, Namier therefore privileged territory over language as a marker of nationality, arguing that linguistic nationalism was a restless and destructive force. By this time, his political allegiance had moved considerably to the right, and it was now a fundamental principle with him that political change had to be incremental and 'organic', rather than programmatic and artificial. A conception of national identity based on language alone ignored the facts of history and the attachment of people to a particular territory, their rootedness in the soil. Territorial nationality, on the other hand, was essentially a benign force. The examples he gave of the latter were Britain and Switzerland, where over time, distinct linguistic and ethnic groups had become attached to the state in which they lived. But this choice was not entirely coherent. Whereas Swiss federalism represented a pragmatic solution to a problem of linguistic and national diversity, Britain, as a political entity, offered its people something more, a cultural identity which transcended other differences. For Namier, British national identity was defined by its prevailing political ideology, 'liberty and self-government have moulded the territorial nation of Britain, and given content to its communal nationality' (Namier 1958a, p. 32). Thus, Britain's 'territorial nationality' derived only partly from the connection of the English with the land they occupied and also from a definition of Englishness founded on an historical commitment to political liberty.

Defining English identity by ethnicity, albeit in this case ethnicity based on political culture, and a historical attachment to land was of a piece with Namier's views on eastern Europe, where his ideas about nationality had been formed. Here, the most obvious example was his belief in the right to self-determination of the various Slavic peoples, and in particular the Ukrainian peasantry of east Galicia, whose cause he took up wholeheartedly during the PolishUkrainian war of 1918-1919, much to the disgust of his own family, who suffered grievously at the hands of Ukrainian forces (Baker 1998). The culture of the peasantry - and its relationship to questions of nationality — was defined for Namier by two qualities, one was attachment to the land and the other religion. The Ukrainian peasants whom he observed in Galicia were an enduring elemental force, identified with the countryside that they worked: 'one needs to have lived in an east-European village', he once wrote, 'to understand the power of the peasant community; governments and masters pass away, but the village commune goes on, a close, self-conscious congregation' (Namier 1947, p. 123). However, this territorial allegiance was essentially local. 'For men rooted in the soil, there is, as a rule, a hierarchy of allegiances: to their village community or estate, to their district, to their "country"-for them the nation is of a naturally federal structure' (Namier 1958b, p. 37). In both world wars, he placed his faith in the ability of the silent, suffering, Slavic masses in the countryside to resist Teutonic aggression, but he was aware that this was simply a matter of endurance, of peasants holding to their own particular piece of land, rather than the inspiration of national sentiment to throw out the foreign invader.

Religion was a different matter and often the single most powerful denominator of nationality. He even applied this calculus to the British empire, where the descendants of English colonists in the new world had inherited the Puritanism of their seventeenth-century 
English forbears along with their love of liberty. He was especially proud that one of his Yankee friends, a banker called Alfred Biddle whom he had met at Balliol, was 'a descendant of the first Puritan settlers', his ancestors having come over on the Mayflower (Greene 1913). In matters of religion, Namier did not write from a personal experience of faith. But from his Sunday church visits as a boy, and his reading, especially in Dostoyevsky, he concluded that religion was at the heart of Russian culture. He wrote repeatedly that Dostoyevsky represented 'the soul of Russia', and this meant also the soul of White Russia (Belarus), and the Ukraine, or, as he called it, 'Little Russia'. Belarus and the Ukraine shared a cultural identity with Russia defined not so much by language as religion. Conversely, the essential falsity in Polish conceptions of nationality was that the Poles had abandoned their Slavic heritage by adopting the religion of Latin Christendom. In describing the three principal demographic groups in east Galicia in his Foreign Office memoranda in 19181920, he customarily used religion rather than language as a denominator; Roman Catholic, Greek Orthodox and Jew was his (not quite accurate) formulation. Catholics predominated in the landed class, and in some towns, but the religion of the majority of the people was Orthodox Christianity, which was an important argument against giving east Galicia to Poland. It was not simply a matter of numbers, however; Polish Catholics were essentially foreigners, either colonial landlords or 'bureaucrats and their hangers-on', whereas Ukrainians constituted the native population. In 1918-1920, Namier applied the same tests to other territories across the Pale of Settlement. In establishing the boundaries of new nation states, he stressed that the principle of territorial integrity had to be applied, but it was a definition of territory based on ethnicity, and ethnicity defined by religion.

Behind religion, of course, lay race. In his willingness to deploy the language of race, Namier was a child of his time, even though in his later years he would disavow the term, as a word mistakenly used in English when 'nationality' was properly meant (Namier 1958c). Thus, his analysis of the geopolitical tensions in Mitteleuropa was founded on notions of racial conflict between peoples originating in the distant past. Germans were 'Teutons', Hungarians 'Magyars', and their political behaviour could be traced back directly to the conflicts between barbarian tribes in late antiquity. He was also perfectly happy to make broad and brusque generalisations about national character, noting, for example, that the various political systems created by 'the German', whether the 'pygmy principalities' of the seventeenth and eighteenth centuries, or the 'Leviathan state' of Hohenzollern Prussia, were alike 'inorganic and grotesque: the work of the typical introvert' (Namier 1949). This phrase, casually thrown down, hints at one source for his cavalier approach to the idea of race, his interest in psychology, especially Freudian psychology, and the power of the subconscious - in this case national character or racial memory - to direct patterns of human thought. Moreover, like Freud, Namier was fascinated by the art and artefacts of primitive civilisations. He had developed an interest in prehistoric archaeology as a young man, when he and his sister discovered on the Koszylowce property a cache of Neolithic objects, including some figurines which may have been fertility symbols (Kaindl 1908; Namier 1971, pp. 59-62). And he occasionally intruded into his historical essays flights of imaginative interpretation, which took a very long perspective; in a review in 1928, for example, he pronounced that 'even the remotest' of all the ages of British history were 'still with us, in the tumuli and monoliths, in the blood and language of Englishmen' (Namier 1928).

The concept of race had also appeared before in Namier's ruminations about 'Britishness' or 'Englishness' (he was never entirely clear about the distinction). The line of argument presented in his 1948 lecture, which defined English national identity partly in terms of a 
shared political culture, was very much a product of his maturity, when his political views had shifted to the right. As a younger man, he had taken a rather different tack. His first attempt at writing history, which he began soon after graduating in 1911, was intended to trace the historical process by which the first British empire had broken up and the American colonies had secured independence. This was the endeavour which eventually issued in his great studies of the eighteenth-century British parliament. But his original aim was tied in with contemporary thinking on empire. He hoped that understanding the causes of the American revolution would facilitate the achievement of one of the visions of Lionel Curtis and the Round Table, with whom he was himself associated ${ }^{4}$ reconciliation between the two great powers and a more effective formulation of the means by which existing British imperial connexions with the dominions could be reinforced. Whilst living in New York in 1913-1914 and pursuing his researches into the eighteenth century, he was heavily influenced by American revisionist historians of the 'imperial school', themselves part of the 'Anglo-Saxonist' movement in American academic life, which emphasised that the evolution of the USA into a constitutional democracy was owing to the colonists' racial inheritance from England (Novick 1988, pp. 8182). Namier's thinking about America took the same line; attending a Fourth of July celebration in 1913, he wondered why his co-revellers should self-consciously proclaim their renunciation of their very obviously British heritage, whilst other 'hyphenated' Americans rejoiced in their national traditions.

I heard Italian, French, Polish and Greek spoken around me. I saw hundreds of little American flags and coupled with them flags of many nations. The one flag which was nowhere to be seen was that of Britain, the land which once had been loved as the mother country, which is now honoured by Americans as the centre of the great sister commonwealth, but which on the 'Fourth of July' is dimly thought of by the multilingual crowd in the New Haven square as a brutal tyrant (Namier 1931, pp. 18-20).

Here, at the root of Namier's understanding of nationality, was a notion of ethnicity in terms of race as well as political and religious culture, for these friends were 'Anglo-Saxons of the purest lineage' (Namier 1931).

\section{Conclusion}

Given his belief that the basis of nationality was primarily ethnic, with race and culture (especially religion) the defining features, and that it was vitally necessary for each nationality to be historically attached to a particular territory, it seems inevitable that Namier would come to embrace Zionism as a political creed, even though he was uncomfortable with Judaism as a religion and sometimes quite sharply critical of his fellow Jews. But his 'conversion' to Zionism was driven by emotional and psychological forces within him rather than being worked out on an intellectual level. He once told his wife that 'he was bound to every Jew with his gut, or rather an umbilical cord which ... tautened agonisingly when one, or a group, fell into dire adversity' (Rose 1980, p. 6). He could see no way for Jews to be released from the 'torture chamber' of eastern Europe, other than emigration to Palestine or to north America, and he used this phrase as early as 1918. Becoming a Zionist was also another manifestation of

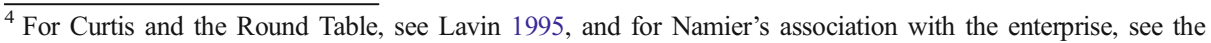
correspondence with or about him in Curtis's papers (Curtis 1913).
} 
his rejection of his upbringing, in the same way as his untiring efforts in 1919-1920 to prevent east Galicia from coming under Polish control. But it also stemmed from the same understanding of the intimate connexion between a national group, defined by race and religion, and its ancestral territory. During the 1920s and 1930s, his dismissive comments about assimilationist Jews - such as his parents - became steadily more vehement, in response to the ill treatment suffered by fellow Jews and even of the treatment he himself suffered; the relatively minor academic rebuffs and disappointments which he came belatedly to realise had something to do with his race. 'In 1921, on my first visit to Vienna after the war', he wrote,

I happened to engage in a discussion about Jewish nationalism and Zionism with one of those high-minded, broad-minded, open-minded, shallow-minded Jews who prefer to call themselves anything rather than Jews. 'First and foremost', he declared in a pompous manner, 'I am a human being.' I replied ... 'I, too, once thought so; but I have discovered since that all are agreed that I am a Jew, and not all that I am a human being. I have therefore come to consider myself first a Jew, and only in the second place a human being (Namier 1942, p. 163).

Open Access This article is distributed under the terms of the Creative Commons Attribution 4.0 International License (http://creativecommons.org/licenses/by/4.0/), which permits unrestricted use, distribution, and reproduction in any medium, provided you give appropriate credit to the original author(s) and the source, provide a link to the Creative Commons license, and indicate if changes were made.

\section{References}

Babel, I. (1961). Collected stories (W. Morison, Trans.). Penguin Books: Harmondsworth.

Baker, M. (1998). Lewis Namier and the problem of eastern Galicia. Journal of Ukrainian Studies, 23(2), 94-96. Bell, Kenneth. (1911). [Letter to G. M. Wrong]. Toronto: Toronto University Library, A67.0007/021.

Berlin, I. (1961). [Letter to Lucy Sutherland]. Oxford: Bodleian Library, Sutherland Papers, Box 9.

Berlin, I. (1980). Personal impressions. London: Hogarth Press.

Berlin, I. (2013). Letter to G. S. Rousseau, 14 February 1972. In H. Hardy \& M. Pottle (Eds.), Building: letters 1960-1975 (p. 479). London: Chatto \& Windus.

Curtis, L. G. (1913). Papers of Lionel George Curtis. MS English History (c. 807, ff 26-8, 44-50, 70-71, 77). Oxford: Bodleian Library.

Davies, N. (2005). God's playground: a history of Poland, ii: 1795 to the present. Oxford University Press.

Fabian News. (1907). November, p. 9.

Greene, W.C. (1913). [Letter to Lady Namier]. John Rylands Library, Namier Papers, 1/19/5. Manchester.

Jewish Chronicle. (1960). October 14.

Kaindl, R.F. (1908). Neolithische Fund emit bemalter Keramik in Koszylowce (Ostgalizien). Jahrbuch für Altertumskunde, ii.

Latawski, P. (1987). The Dmowski-Namier Feud, 1915-1918. Polin: studies in Polish Jewry, ii, 37-49.

Lavin, D. (1995). From empire to international commonwealth: a biography of Lionel Curtis. Oxford: Oxford University Press.

Leeper, A. (1908). [Letter to his parents]. Balliol College Leeper Papers, IIA. Oxford.

Mackinder, H. J. (1904). The geographical pivot of history. Geogr J, 23, 421-437.

Namier, L. (1914). Germany and eastern Europe. Political Quarterly, 4, 70-93.

Namier, L. (1915). Germany and eastern Europe. London: Duckworth \& Co..

Namier, L. (1918). Memorandum. The National Archives [of the U.K.], FO 371/3135, file 416.

Namier, L. (1919). Memo. The National Archives [of the U.K.], FO 371/3903, file 38028.

Namier, L. (1920 23). Russian land and Polish men. New Europe.

Namier, L. (1922). Drafts and notes for Waynflete lectures. Notes. Bodleian Library (MS English History, D. 341-2). Oxford.

Namier, L. (1923). The problem of east-Central Europe. Round Table, 49, 569-590.

Namier, L. (1924a). The downfall of the Habsburg Monarchy. In H.W.V. Temperley (Ed.), A History of the Peace Conference of Paris (chapter 1). London: Oxford University Press. 
Namier, L. (1924b). [Review of the book The Agrarian Revolution in Rumania, by I. L. Evans]. Nation and Athenaeum 35.

Namier, L. (1928). [Review of the book The history of British civilization, by E. Wingfield-Stratford], Nation \&Athenaeum.

Namier Sr., L. B. (1930). Who's who. London: A \& C Black.

Namier, L. (1931). Skyscrapers and other essays. London: Macmillan \& Co..

Namier, L. (1942). Conflicts: studies in contemporary history. London: Macmillan \& Co..

Namier, L. (1944). 1848: The revolution of the intellectuals. Proceedings of the British Academy. Xxx (pp. 161282).

Namier, L. (1947). Facing east. London: Hamish Hamilton Ltd..

Namier, L. (1949). The German wars. National Review, 133(795), 491-506.

Namier, L. (1951). [Letter to Basil Liddell Hart]. King's College, London, Liddell Hart Centre for Military Archives (Liddell Hart papers, LH 1/539/63).

Namier, L. (1954). [Letter to Philip Friedman]. Center for Jewish History (YIVO Archives, Friedman papers, RG 1258, Folder 164). New York.

Namier, L. (1958a). Nationality and liberty. In L. Namier (Ed.), Vanished supremacies: essays on European history, 1812-1918 (pp. 31-53). London: Hamish Hamilton Ltd.

Namier, L. (1958b). Basic factors in nineteenth-century European history. In L Namier (Ed.) Vanished supremacies: essays on European history, 1812-1918 (pp. 165-75). London: Hamish Hamilton Ltd..

Namier, L. (Ed.) (1958c). Vanished supremacies: essays on European history, 1812-1918. London: Hamish Hamilton Ltd.

Namier, J. (1959). A turbulent Zionist. Unpublished typescript. House of St. Gregory \& St. Macrina, Babington Smith Papers, Oxford.

Namier, J. (1961). [Letter to Lucy Sutherland]. Bodleian Library (Sutherland Papers, Box 9). Oxford.

Namier, L. (1966). England in the age of the American revolution (p. 2268). London: Macmillan \& Co.

Namier, J. (1971). Lewis Namier: a biography. Oxford: Oxford University Press.

Ng, A. (2004). Nationalism and political liberty: Redlich, Namier and the crisis of empire. Oxford and New York: Oxford University Press.

Ng, A. (2005). A portrait of Sir Lewis Namier as a young socialist. J Contemp Hist, 40(40), 621-636.

Novick, P. (1988). That noble dream: the 'objectivity question' and the American historical profession. Cambridge and New York: Cambridge University Press.

Oman, Sir C., (1917). [Letter to Sir Eric Drummond]. The National Archives [of the U.K.] (FO 371/3016, File 229).

Paton, H. (1962). [Letter to Arnold Toynbee]. Bodleian Library (Toynbee Papers, Box 84).

Rose, N. (1980). Lewis Namier and Zionism. Oxford: Clarendon Press.

Schutz, E. (1994). My long journey to London. Private Press.

Shanes, J. (2012). Diaspora nationalism and Jewish identity in Habsburg Galicia. New York: Cambridge University Press.

Smith, A. L. (2004). Oxford dictionary of national biography. Oxford University Press. Retrieved from: http://www.oxforddnb.com/.

Stern, E. (2013). Elijah of Vilna and the making of modern Judaism. New Haven \& London: Yale University Press.

Sutherland, L. (1971). [Letter to Julia Namier]. Oxford: Bodleian Library (Sutherland Papers, Box 9).

Taylor, A. J. P. (1983). A personal history. London: Atheneum Books.

Toynbee, A. (1967). Acquaintances. Oxford University Press.

Wingate, Sir R.. (1914). [Letter to Lord Kitchener]. The National Archives [of the U.K.] (Kitchener papers, PRO 30/57/45). London 